\title{
Integrated Regional Development Policy Formulation in Ethiopia
}

\author{
Kemal Abdela Kaso ${ }^{1}$, Sukanya Aimimtham ${ }^{1}$, Sukhumvit Saiyasopon ${ }^{1} \&$ Weerakul Chaiphar ${ }^{1}$ \\ ${ }^{1}$ Public Administration Department, Humanities and Social Sciences, Graduate School, Khon Kean University, \\ Khon Kean, Thailand \\ Correspondence: Kemal Abdela Kaso, Public Administration Department, Humanities and Social Sciences, \\ Graduate School, Khon Kean University, Khon Kean, Thailand. Tel: 66-9-1563-5067. E-mail: \\ kemalorom@gmail.com
}

\author{
Received: April 2, $2018 \quad$ Accepted: June 25, $2018 \quad$ Online Published: November 30, 2018 \\ doi:10.5539/jpl.v11n4p153 URL: https://doi.org/10.5539/jpl.v11n4p153
}

\begin{abstract}
This research aims (1) to study the practice of an Integrated Regional Development Policy Formulation (IRDPF) in Ethiopia and (2) to explore and identify the challenges of integrated regional development policy formulation in Ethiopia. The research is conducted by collecting data from 20 purposely selected key informants from both the federal and regional government sectors, political parties and community in Ethiopia. Data are collected through in-depth interviews and review of relevant documents, and systematically analyzed using content analysis technique. The results show that the practice of policymaking and IRDPF process in particular is not in line with of the law of land, in which the executive branch, particularly, the Prime Minister and ruling party's elites are the key actor in the process at both federal and regional levels with limited consultation and participation of other House of Peoples Representatives, federal and regional policy makers, and other stakeholders. The study also identified various political, social, economic and technical challenges that affect sound and effective integrated regional development policy formulation in the country.
\end{abstract}

Keywords: formulation, integrated, policy, regional development

\section{Introduction}

The life of every single community is changing from time to time because of globalization that provides new opportunities and challenges, which force the government and other concerned sectors to address it in order to bring a sustainable economic and social development. Accordingly, in every country, the government that is the key responsible sector has to respond to the problems arises and bring socio-economic changes that are base for the growth and development - wellbeing of the citizens of the country through making policies. But policymaking itself has been an issue and thus, there have been a continues efforts to improve policy making. Many have been expressing their concerns about how the policies are made and their effectiveness in solving the problems of the society. This is no exception to Ethiopia consecutive governments that have been striving to formulate policies to overcome the socio-economic, political as well as environmental challenges and problems the country has been facing.

Ethiopia has a long history and experience in medium and long-term planning/policy formulation starting with the three consecutive 5-year plans of the 1957-1961 period followed by the ten-year plan of 1984/85-1993/94 period. Because of the past political systems and other factors several past national development oriented regional policies were not capable of addressing real regional problems. According to Tiruye Alemu (2015) the then political challenges urged the government to establish a constitutional state to realize democracy, needs institutions that are capable of formulating good policies to get agreement from the political participants and achieve the intended purposes. Accordingly, in 1995 Ethiopia adopted a new constitution called Federal Democratic Republic of Ethiopia Constitution (FDRE Constitution in short) that brought some constitutional, political changes and of course, influenced the policy making process in the country. It established a new federal structure of government, whereby power is shared between the center and the regional government both being autonomous in certain clearly defined areas. The regional governments are responsible for a administering their areas except for foreign relations, defense, and general policies of common interest and benefit, which are the responsibilities of the Central Government. The country also structured along the lines of bicameral parliament consisting of a Federal Council and a House of Peoples' Representatives where both a federal government and a state shall have legislative, executive and judicial powers. 


\section{Policymaking in Ethiopia}

The strength of policy making is vital to the governmental strength and the country in general. Recognizing the importance of policy, as mentioned above the Ethiopia government has been making efforts to bring a policymaking change. As per the plan of the Ethiopia government, policymaking in Ethiopia should be a systematic, inclusive and that follow the acceptable policymaking stages and process including identifying the problems, analyzing the problems and evidences, setting the priorities based on evidences, formulating draft policies, consulting the key stakeholders to test the draft policy, reviewing, formulating and implementing the policy. However, it has been reported as the process of policymaking in the country lacks the fundamental elements of the process. T. Brow and A. Teshome (2007) reported that the policy making in Ethiopia is not following a systematic and consultative procedure rather it a less systematic and less consultative as well as 'top down approach while a genuine bottom-up policy process is possible and preferable. For instance, the Addis Ababa Integrated Regional Development Plan formation was opposed and criticized by the outside observers, Oromia regional government officials, some member of parliament, students, oromo people and some other stakeholders as it lacked consultation with these stakeholders and was formulated as per the wish and interests of the elites.

The political roles and ideology of the ruling party shaped the policymaking process, in which its ideas and interests prevailed and intertwined with the policies and structures of government both at federal and regional levels. In principle, however, in the process of policymaking the responsible bodies are not only politicians, but also representatives of the people, experts and scholars, especially in today's 'administrative state' era, with the rapid expansion of government functions and the extensive use of administrative discretion, administrative authorities are involved in public policy initiative growing (as cited in Renzong Huang, 2002). Moreover, Tiruye. A (2015) conducted a research on the policy making practice and the challenges of House of Peoples' Representatives (HoPRs) in Ethiopia, which aim to assess a broad sense of the present circumstance of Ethiopia legislatures, their roles in policy making process, institutional capacity and potential to become an important actor in policy making process as per the law of the land. The result of her study identified that the fusion of power between the executive and legislative branches and strong party discipline limited the contribution of a bicameral structure to policy making process, less involvement of opposition parties in the house, limited citizen's participation in policy making process, and low institutional capacity of the house as main factors that affecting the effective policy making role of the legislatures in Ethiopia. This show that the policymaking process in the country lacking the crucial policymaking elements discussed above. Although the sources show the defects in stages/process or approach to policymaking in general there is no data specifically in the area of integrated regional development and policy formulation stage, which is very important phase of the policy process and an integral part of policy design. Thus, this research aims to study the practice and challenges of integrated regional development policy formulation Ethiopia.

\section{Objectives}

The objectives of the research are (1) to study the practice of an integrated regional development policy formulation in Ethiopia, and (2) to explore and identify the challenges of integrated regional development policy formulation in Ethiopia.

\section{Research Methodology}

The overriding purposes of this research study were: (1) to study the integrated regional development policy formulation in Ethiopia, and (2) to explore and identify its possible challenges of integrated regional development policy formulation in Ethiopia. In order to achieve these overall objectives, two main research questions were framed this study. These were: (1) what is the practice of integrated regional development policy formulation? (2) What are the challenges of integrated regional development policy formulation? The research was conducted through semi-structured interviews with key informants, and review of relevant documents. The key informants of this study were comprised of four federal policy and planning officers, four regional policy and planning officers, two regional administrators, two political party leaders, two political analysts, two lawyers and four community members in Ethiopia. Of the 20 informants most respondents were in the 33- 52 years old; 7 were female and 13 were male (Table 1). On average, the participants had over 7 years of professional experience. 
Table 1. The key informants of the study

\begin{tabular}{lccc}
\hline Informants & N & Males & Females \\
\hline Federal policy \& planning officers & 4 & 3 & 1 \\
Regional policy \& planning officers & 4 & 2 & 2 \\
Regional administrators & 2 & 1 & 1 \\
Political party leaders & 2 & 2 & - \\
Political Analysts & 2 & 1 & 1 \\
Lawyers & 2 & 1 & 1 \\
Community members & 4 & 3 & 1 \\
\hline
\end{tabular}

The key informants were recruited based their current and previous positions, and longtime experiences from each sector appropriate to the subject matter via phone and email. The interview questions were developed and sent to the key informants via email. The researcher invited the key informants to informally discuss about the subject matter of this study with the aim to gather detailed data relevant for this study. All informants were asked the same an open-ended question to determine the practice and challenges of integrated regional development policy formulation process with emphasis on the principles as per the law of the land, the roles of key actors or policymakers in practice, the participation and approaches to policy formulation. They were also asked to explain the possible factors that have both positive and negative impacts on the effective policy formulation. The interviews were tape-recorded and systematically analyzed using content analysis techniques.

The research findings are based on analysis of the following data sources: In-depth- interviews, and review of relevant documents. A number of issues related to the policy formulation practice and the challenges of an integrated regional development policy formulation were obtained from the interviews with the informants of the study, and review of relevant documents. Generally, two parts emerged from the data are:1) The practice of integrated regional development policy formulation, and 2) Challenges to Integrated Regional Development policy formulation. While the topics are reported as being discrete, there is considerable overlap among them. Further, participants' responses to interview questions often addressed more than one topics. In those cases, the interview data are described where they appear to fit most logically.

\section{Research Findings}

\subsection{The Practice of Integrated Regional Development Policy Formulation}

The majority of federal policy and planning group's respondents reported that in a current Ethiopian political system policy are prepared at national and regional levels where national policies are prepared by the federal government and within the federal government following the formal procedure of policy making. Majority of this group's respondents reported that:

The committees and the parliamentary groups have the right to initiate draft bills, and the bills come to the legislature then signed by the respective initiator and given to the speaker. The bill is approved as an agenda item by the business advisory committee and presented to the plenary session. Before the discussion, representative of the policy initiator brief to the house on the contents and importance of the bill. After the briefing the first reading debate is taken place by focusing on general issues. As the first reading is concluded, the bill either will be referred to relevant standing committee for further scrutiny or directly, if motion is moved, it will be passed to second reading and enacted as a law. The bill referred to the concerned committee after the first reading passes several stages prior to its approval by the House. Firstly, the committee to which the bill is referred has to examine carefully and in detail. After the committee members make it clear themselves it is important to identify issues and questions to be clarified and answered by the initiator. The next step will be inviting the initiator government department heads and professionals to explain the purpose and importance of the draft bill and answer the questions prepared by the respective standing committee beforehand. The representative of the initiator government department gives clarifications over the vague issues and give answers to the questions from the standing committee and participants of the forum. If the bill under question is to have deemed affect public interest, public hearing will be organized by the focal committee. The public forum is represented by different stakeholders who may include mass organizations, professional associations, civil society organizations (CSOs) and higher education and research institutions, 
chambers of commerce, public institutions, interested groups and individuals. These stakeholders are invited through broadcast media publicly and through letters individually along with the copy of the agenda to make necessary preparations in advance.

Thus, according to these respondents the policies are initiated by the right policy actors and passes through several stages before approval. However, some of the respondents of this group reported that the federal executive branch plays much more role during the policy formulation process.

For example, respondent $\mathrm{J}$ said that:

In Ethiopia, executive branch of the federal government highly influenced the process of formulation at all levels, and the legislative branch of the government- the highest law-making power has limited role in the process of policy formulation in Ethiopia. Some critical policies that rule or guide the existing system have been emanating from the Prime Minister (PM), who is the commander in-chief of the army, the chairman of EPRDF and TPLF -as a single person. The PM together with his team write/ initiate, paper and present the proposal at the EPRDF executive committee meeting and explain the aim and advantages of the policy. Then a few questions or ideas are thrown from the members of the committee. Then the policy approved with some corrections and changed to the laws. The peace and security policy, foreign policy, agricultural policy, industrial policy, poverty policy and other developmental policies such as integrated regional development policy were some of the policies that prepared in the above-mentioned system.

The researcher also asked if all policies were formulated in the similar process. They said that some minor policies that are also initiated and prepared within the ministries.

Respondent J1 said that individual ministries proposed certain policies under the dictation of the PM, who may reject or kills the policies by delaying for long period of time-two or three years. In short, the policies are initiated, prepared or designed by the prime minster and close officials, discussed among themselves, and then call for a meeting for adoption.

The regional policy and planning respondents were asked about the formulation of regional policies. The finding show that the regional states have power over regional matters and have been formulating regional policies to as per the needs of the regional people. However, one respondents, $(\mathrm{J})$ said that:

The regional policies are the subsets of the federal polices emanated from the same policymaking system where the executive branch shape the policies as per its interest or interests of federal government. More than $90 \%$ of the regional polices are not original or independent policies that were necessitated by the need of the regional state itself, initiated and prepared following the formal policy formulation process stipulated in the constitution of the country, and based on the needs and interest of the people in the region where the issues that the policies are needed.

The information obtained from the lawyers, political analysts and political parties members show that at the federal level policies are formulated based the system enshrined in the law of the land, but majority of regional policies derived from the federal policies that are formulated for the nation of the country. They also reported that the federal government has been influencing the regional governments and it has been shaping the regional policy formulation even implementation.

Respondent $C$ said that the federal government influence on the regional governments violate the principle of separation of power, which is one of the key elements in federal system of government. Constitutionally, the regional states how duty to decide on their matters and formulate the right policy that solve the regional problems. But this is not the practice in Ethiopia where the constitutional principles or procedures have been not followed.

Moreover, respondent B one of the members of political party in the country reported that:

Policy formulation in the country is monopolized by the ruling party both at national and regional. The policies have been framed as per the ideology of the ruling party or the officials on the top position. This system does not allow other interested group to participate in the policy formulation process. This in turn leads to ineffective policy, which it's implementation would a big headache for the implementers. This is no exception to the integrated regional development policy formulation as it is one of the crucial policies that the elite monopolize.

According to the respondents the practice of the policy formulation in Ethiopia is influenced mainly by the executive branch of the federal government, whereas other sectors are less consulted and participated during the 
formulation of policies. Moreover, the regional governments have less role in the process of an integrated regional development policy formulation.

\subsection{The Challenges of Ethiopia's Integrated Regional Development Policy Formulation}

Although the opinions of the respondents of federal policy and planning group varied, majority of them reported that there was less room of participation for the people and other stakeholders in the policy formulation process in Ethiopia. Respondent $\mathrm{T}$ who has been serving the federal policy and planning sector for many years said that:

The ruling elite within the government are the stakeholders who participate in the process of crucial policies making in the country. The policies follow the interest of elites or ruling party not public interests at large. So, there is no chance for the citizens or the representatives and other stakeholders' participation in process at this stage, and I am afraid to say that the principle of citizens' and other stakeholders' participation is not in practice in Ethiopia.

According to this respondent, therefore, citizens and other stakeholders are not taking part in the process of the policy formulation. However, respondent $\mathrm{E}$ who is also senior staff of policy and planning sector said that:

The nation, nationalities and people of Ethiopia have full right to either directly or indirectly participate in any developmental initiatives as per the constitution of the country. At the federal level policy makers have been consulting not only with representatives of the citizens but also with other stakeholders that supposed to take part in the policy formulation process, especially, in an integrated development policies formulation.

The lawyers and political analysts were also asked the same question. All lawyers informed that all the nation, nationalities and people as well as any other interested sectors from individuals companies to NGO's have right to participate on the policymaking as per the law of the land. As for the practice of the participation in the country they said that the citizens and other stakeholders have been taking part in the policymaking process.

For instance, respondent $H$ said that although the level of participation is less as compared to other democratic country, the policymaking system of Ethiopia allows any interested party to participate in the process of policy making. But at the policy formulation stage the participation is very low. Only few federal government officials and legislature are the stakeholders and approve the bill and then work towards its implementation where there is high level of participation of citizens and stakeholders.

In contrast, the data collected from the ordinary individuals, private companies' and NGO representatives show that there is limited room for them to participate in an integrated regional or any other policy formulation process in the country. Moreover, members of political parties' also reported as there is very limited room for consultation and participation of citizens, political parties, and other stakeholders that supposed to have role in a democratic policy formulation process.

Respondent $J$ who was serving several offices both in federal and Oromia regional government confirmed the opinion of this by saying that the citizens and other stakeholders have been invited only when the policies are running into a big problem and a lot of murmur within the community or affected people, and then people are gathered in a big hall for a meeting and discussion. He said this is a crises management which is not democratic public or stakeholders' participation. He also added that the Ethiopian government calls for the public meeting when there are resistances to, or violence because of the policy not to share or take their ideas that need to put into the policy and answer their questions but to convince or force them to accept it.

As far as the approach to policy formulation is concerned, all participants argue that the policy formulation in Ethiopia doesn't follow the FDRE constitution's principles that clearly stipulated the approaches that allowed all citizens and other stakeholders to take part in the process of policy formulation, particularly integrated regional development policy or plan. They concluded that top down approach practiced in Ethiopia's policy formulation at all levels.

The current political unrest in the Federal Democratic Republic of Ethiopia (FDRE) is also reported as one of factors that influence an integrated regional development policy formulation in Ethiopia. The politics in Ethiopia is one of main problems that the country is facing, and shape many developmental policies including an integrated regional development one. The constitutional questions and the question of the existence of Ethiopia as presently constituted and advocate its restructuring, which is another way of asking for a review of the administration system are among the political questions that contribute to the political crisis in the country. However, there are some participants who argue that neither the constitution nor the existing system is the problem, but the absence of good governance that leads to corrupt politicians/ leaders are the problems. 
One of the participants (Ch.) stated that: I don't think the FDRE constitution is the problem as it is the copy of the western constitution and included all the basic fundamental developmental policies principles or procedures that fit the country. However, the implementation of the procedures has been big problem that hinders the realization of many national and regional developmental policies including the integrated ones.

The participants also reported that the absence of good governance, corruption and ethnic conflicts are the challenges that affect the sound integrated policy formulation and even implementation.

One participant (J 1) who has been working with the current ruling party and assigned in different high position reported that: the political culture is a big challenge and plays a dominated role in policy formulation of Ethiopia in general. Major policies are formulated on the basis of interest of elite groups like politician, bureaucrats and businessman. In this aspect, he said, the empowering government makes policy according to their own strategy. And the opposition and the interest of general people are ignored there. Thus, in the policy formulation there is lack of democratic values in the country, which is because of lack of institutionalization of democracy in political process.

Moreover, the finding of the study also shows that the federal and regional governments' power relation, the absence of institutionalization and coordination are among the challenges that have impact on the integrated regional development policy formulation and even implementation.

Respondent $L$ said that although the constitution clearly expressed the policy formulation power of both federal and regional governments, the federal government has been formulating integrated regional policy without regional governments' consultation. The regional governments have power to formulate regional policies and participate in the formulation of an integrated regional development plan or policy. But in practice the federal government decides over the matter of regional states, which is in violation of principle of separation of power and remains the challenging issue for the current system of the country.

As per the information discussed above, therefore, political unrest, constitutional and the question of the existence of Ethiopia, lack of good governance, corruption, ethnic conflicts, the absence of institutionalization and coordination among the federal and regional, and issue of separation of power are the political challenges the country is facing.

The study revealed not only political challenges, but also some current social issues that affect or shape the formulation of an integrated regional development policy. Majority of the respondents said that social exclusion, marginalization, inequalities of individuals and ethnic groups are the key factors that affect not only the effective policy formulation but also the social life of the society of the country.

Respondent $J$ said that social divisions between racial and ethnic groups-along economic, cultural, and political lines have been the feature of Ethiopia people life through all the systems of the country and inhibit the full participation of individuals in a society's social, economic and political life.

Some of the respondents also said that although the level of marginalization and discrimination decreasing, it remains one of the problems that affect people's participation in policy formulation and other political decision-making process and have been a cause for political unrest and civil conflict. They added that equal and inclusive participation of a diverse citizenry in public and private life is a fundamental aspect of a peaceful and just society. And they suggested that the government needs to improve opportunities for its citizens to participate as per the constitution of the country.

The study revealed that absence of equal access to rights, opportunities (such as employment), or resources (like healthcare, education) are also the factors that are influencing the effective policy formulation as it affects the participation of the citizens. Moreover, some interviewees said that an explosion in population, the difficulty in accommodating the diverse interest of nation, nationalities and people as well as the socio-cultural diversity in the country is also one of the national problems that has impact on the integrated regional development policy formulation in the country. In addition, all informants in this study reported that low level of country's economy, a limited capacity, skills, and financial resources are the challenges that hinder the proper formulation of an integrated regional development policy that goes along with the 21 st century citizen's needs.

One of the participants (Ts) said that the economy is one of the key element for the effective national development policy or plan formulation in every country. But in Ethiopia the low economy has been some challenges for the country that highly affected the overall developmental initiatives.

Some informants also informed a researcher that shortage of skilled man power in the areas of integrated 
planning, shortage of budget, and lack of long term planning are some of the challenges that needs due attention. Moreover, they also said that technical resources such as technology, equipment and infrastructural development that help to make sure policy effectiveness also the key element and need to be improved.

Respondent Ch said that policymakers in Ethiopia need to consider the existing technology before formulation of an integrated development plans. She also said that the current technical resources are very limited when compared with required elements of integrated development policy formulation and implementation.

\section{Discussion and Conclusion}

Unlike the unitary form of system, the federal system is a system of governance with diverse features of power sharing, in which the power is given to the central government is given power from the reginal states or the constituent unites. In case of Ethiopia, the nations, nationalities and people are the sources of power and each regional government has its own power as per the constitution of the country. But this study reveals that the practice of policy formulation process in Ethiopia is not always in line with the constitution of the country and the principle of constitutionalism. The findings show that most policies that rule or guide the existing system are emanating from executive particularly, the Prime Minister (PM), who is the chief executive, the chairman of the council of ministers, and the commander- in-chief of the national armed force, and council of ministers. And there is limited legislative branch role, and other policy actors at both federal and regional levels. The study of T. Alemu (2015) confirmed that almost all the laws/policies passed by Parliament have originated from the executive and the legislatures were engaged in reviewing and approving legislation. This can be seen as justified by Howlett and Ramesh in T. Alemu(2015) that in parliamentary systems where the legislators belonging to the governing party and where the membership is tightly organized along party lines, and marked by a high degree of cohesion and discipline, permit little opportunity for legislators to take an independent stand. Thus, the executive branch of the government has a greater influence on Ethiopia's integrated regional development policy formulation, whereas the legislative and other federal and regional government sectors who have mandate to participate in the process have limited access to participate in this crucial stage of policymaking process in which the fundamental steps should be followed and other policymakers need to discuss and suggest approaches to correcting problems that have been raised as part of the agenda.

Another point of discussion is citizens' and other stakeholders' participation in the process of integrated regional development policy formulation in Ethiopia. The early stages of the public policy formulation are aimed at achieving maximum 'consultation' and 'participation' of the people in policy formulation since public policies are about matters affecting them, and thus, a policy initiated should reach a consensus based on the opinions of those consulted. And the activities take place from both the executive and legislative ends in policy formulations to ensure that all possible influences that should bear on a policy proposal are taken into account (Bukar Usman 2017). To formulate a successful policy, therefore, it needs to have a positive effect on the problem, support from legislators and public officials, and the public need to accept it. However, the findings of this study show that the citizens and other stakeholders' participation is less, and the ruling elite within the Ethiopia federal government are the stakeholders and the system only in the interest of elites or ruling party not public interests at large. This is contrary to article 89(6) of Federal Democratic Republic of Ethiopia constitution that stated the government shall at all times promote the participation of the People in the formulation of national development policies and programs; it shall also have the duty to support the initiatives of the People in their development endeavors. Article 43 of Federal Democratic Republic of Ethiopia constitution also stated that the people, nations and nationalities of Ethiopia have the right to development, and particularly, the right to participate in national development and to be consulted with respect to policies and reject projects affecting their community. Therefore, it implies that there is a limited room for public and stakeholders' participation in the process of Ethiopia policy formulation.

Moreover, the study reveals that the current political and socio-economic problems and challenges that have an impact on the integrated regional development policy process in Ethiopia. The political tension between the federal and regional states, and among the regional states in the country is result in the current social problems such as exclusion, marginalization, inequalities of individuals and ethnic groups and absence of equal access to rights, opportunities and resources, and low level of country's economy. The studies show that

exclusion prevents individuals and groups not only from contributing to the economic, social and political life of their society, but also it could lead to social tensions and conflicts and negatively affect the effective integrated regional development policy formulation. Excluding some group's also results in an underutilized resource for economic activities that are basic for an integrated development approach that aims to contribute to harmonizing and integrating plans and strategies at different governmental levels and between different administrative sectors. 
According to UNCRD (2013) report an integrated regional development plan/policy is

participatory planning and decision-making for a region, which offers a very powerful tool to promote sustainable development by addressing some sustainable development issues such as the inclusion of the poor and marginalized segments of the population and all other relevant stakeholders in the planning process; addressing the issues of concern of the local people and communities; identification of priorities of issues to be addressed, which implies that issues will be addressed in an integrated manner; many areas of developing countries are affected by threats of climate change, other extreme weather events, and environmental degradation, which implies that the planning process will have to include disaster governance and management; and land degradation/desertification and persistent drought conditions can compound the issues of agricultural production and food security, which will ultimately affect livelihood security of rural farming community.

Thus, the social issue, which is the result of politics is one of the factors that affect the integrated regional development policy formulation in Ethiopia. The economic level of Ethiopia, which is influenced by the prolonged poverty and of course the politics is also reported as one of the factors that determines the formulation of a complex and sophisticated integrated development plans or policies in the country. Majority of the respondents of this study say that the low level of economy of the country is result in limited technical resources, capacity, skills, and financial resources that are key elements and crucial to assure the effectiveness of integrated regional development policy formulation. Conclusion There is a

gap between the theory/ principle and practice of integrated regional development policy

formulation in Ethiopia in which few government officials on the top are the key actors whereas the people and other stakeholders have limited participation in the process. Thus, the process is less consultative, exclusive and top down process. The politics of the country that causes the economic and social problems affect the formulation and realization of integrated regional development policy.

Therefore, to formulate an effective regional development policy that equally benefits the community, the study suggests a systemic integrated regional development policy formulation procedure and ways of participation that are paramount to increase the effectiveness and overall practice of policy formulation in Ethiopia through promoting good governance that creates peaceful co-existence, a sound political linkage and coordination among different governmental levels and administrative sectors in the country. It also suggests utilizing the existing human and natural resources effectively to minimize the economic challenge the country is facing. Further studies are needed to understand the jurisdiction of an integrated regional developments policy formulation of in Ethiopia. The federal government interference into the regional affairs can be one the factors that creates political instability among the federal and different regional administrations.

\section{References}

Addis Ababa MoFED. (2010). Ethiopia: Country report on the implementation of the Brussels Program of Action (BPOA). Ethiopia: Ministry of Finance and Economic Development

Advocacy for Oromia. (2015). The agenda behind the integrated regional development plan. Victoria Australia: Advocacy for Oromia.

Agarwal, O. P., \& Samantha, T. V. (2005). Public policy making in India: Issues and remedies. Indian $J$ Otolaryngology, 26, 110-111.

Alemu. T. (2015). Policymaking practice and challenges of House of Peoples Representatives (HoPRs). Sky Journal of Agricultural Research, 4(7), 132-146.

Anderson, J. E. (2003). Public policymaking: an introduction. Boston: Houghton Mifflin.

Andrew, K. J. B., \& Susan, V. (2004). Working in organizations (2nd ed.). New York: New York Historical Society.

Answer.com. (2011). What is policy implementation and what are the three elements to implementation? [n.p.].

Aragone, E., \& Sanchez, S. (2008). A theory of participatory democracy based on the real case of Porto Alegre. European Economic Review.

Ararssa, T. R. (2015). Why resist the Addis Ababa master plan: A constitutional exploration. Ph.D. Dissertation, Graduate Research Student at the University of Melbourne.

Arun, J. (2014). Integrated urban design and planning for inclusive public space and city- region connectivity and efficiency. International Journal of Green Energy, 11(9), 969-986.

Asebe, R. (2015). Why do Oromo resist the Finfinnee (Addis Ababa) master plan. Ethiopia: Three-year 
Retrospective Study.

Astrid, B. (2004). Strategic analysis: An adapted model for implementation evaluation. Retrieved October 25, 2017, from http:// www.scie-socialcareonline.org.uk/

Augustine, N. E. (2010). Public policy analysis. Retrieved October 25, 2017, from https://www.ncbi.nlm.nih.gov/pubmed/11423032

Barder, O. (2012). What is development?. Retrieved November 10, 2017, from, http://www.cgdev.org/blog/what-development

Béla, B. (2013). Integrated regional development. [n.p]: Theoretical Textbook.

Berhanu, A. (2014). Public policy making in Ethiopia. Ethiopia: Jimma University.

Birkland. (2010). An introduction to the policy process: Theories, concepts, and models of public policy making. Carolina: School of Public and International Affairs, North Carolina State University.

Boundless. (2016). Rational decision making. Retrieved October 25, 2017, from https://courses.lumenlearning.com/boundless-management/chapter/rational-and-no rational-decision-making/

Brodie, E. et al. (2009). Understanding participation. The Writing Center.

Bukar, U. (2017). Public policy formulation in Nigeria: challenges and prospects: executive-legislative relations: gaps, challenges and prospects. [n.p.]: The Writing Center

CAJ Consultants. (n.d.). Participation: a theoretical context. Retrieved October 25, 2017, from http://www.sharedservicearchitects.co.uk/write/Documents/Citizen_Participation_Theoretical_Frameworks. pdf

Canoy, M. (2014).Tourism development \& policy formulation. Christaller's Theory.

Charles, C. (2011). Policy implementation in multilevel environments: Economic development in Northern Ontario. San Diego: United States Assistant Secretary for Health.

Cohen, D., \& Crabtree, B. (2006). Qualitative research guidelines project. Retrieved October 25, 2017, from $\mathrm{http}: / /$ www.qualres.org/HomeSemi-3629.html

Commonwealth of Australia. (2000). Good governance; guiding principles of implementation. Australia: Commonwealth of Australia.

Connective Cities. (2016). Good-urban-governance. Retrieved October 25, 2017, from http://www.connective-cities.net/en/topics/good-urban governance

Croft, J. (2011a). Civic group participation in public policy process. London: UK. London School of Hygiene \& Tropical Medicine.

Croft, J. (2011b). Transitioning from hierarchy to network: A paper on the evolution of governance. London: UK. London School of Hygiene \& Tropical Medicine.

Dennis, A. R. (2007). Public administration and democratic governance: Governments serving citizens.

Diaswati, M. P., \& Yuka, S. (2008). Implementation of good governance by regional governments in Indonesia: The challenges. London: Springer.

Euro cities. (2016). Integrated urban development.

European Union. (2011). Priority Axis 1: sustainable and integrated urban development.

Ezugwu, E., \& Mechael, C. (2013). Policy implementation and national development: A case study of Japan and Nigeria railway policies.

Floridia. (2013). Participatory democracy versus deliberative democracy: elements for a possible theoretical genealogy: two histories, some intersections. California: American Pediatric Surgical Association.

Frank, F., \& Miller, G. J. (2007). Handbook of public policy analysis theory, politics, and methods. New York: Marcel Dekker.

Gabriel, P., \& Simona, P. [n.d.]. Integrated urban development through participatory approach. [n.p.]: A Romanian story.

Ghodoosi, F. (2016). The concept of public policy: Revisiting the role of the public policy doctrine in the enforcement of private legal arrangements. Glob J Health Sci., 8(10), 56478. 
Hai, D. P. (n.d.). Process of public policy formulation in developing countries. Vietnam: Faculty of Public Policy, Graduate Academy of Social Science (GASS).

Hedley, S., \& Stephen, P. (2008). Collaborative relationships in construction: Developing frameworks and networks. Illinois: University of Illinois at Urbana-Champaign.

Huang, R. (2002). On the nature of public policy. Beijing: Peking University, Beijing Chinese Public Administration Review.

Institute for government. (2014). Improving policy implementation. Institute for government.

Jans, M. T. (2007). A framework for public policy analysis and policy evaluation. Hum Pathol, 14, 780-797.

Kö, A., Gábor, A., \& Szabó, Z. (2013). Policy making improvement through social learning. Berlin: Springer. https://doi.org/10.1007/978-3-642-40160-2_18

Linked In Corporation. (2016). The challenges in policy formulation, policy analysis and implementation in developing countries. Economics, Library of Economics and Liberty.

Meiring, M. H. (n.d.). The nature and importance of policy analysis and evaluation in the local sphere of government. Pretoria: Kagiso.

Ministry of Finance and Economic Development. (2010). Ethiopia: country report on the implementation of the Brussels Program of Action (BPOA). Ethiopia: Ministry of Finance and Economic Development.

Mohammed, S., \& Mahbubur, R. (2008). Challenges of policy formulation and implementation of primary education in Bangladesh. A conceptual analysis. New York.

Nagoya University. (2013). UNCRD expert group meeting on integrated regional development planning. Japan: Nagoya University.

National Democratic Institute. (n.d.). Citizen participation. Retrieved October 25, 2017, from https://www.ndi.org/citizen-participation

National Planning Commission. (2015). Ethiopia's mid-term review on implementation of the IPoA. National Planning Commission.

New Mexico Department of Finance and Administration. (1995). Community planning: steps in comprehensive planning. Retrieved November 10, 2017, from http://nmdfa.state.nm.us/Steps_in_Planning.aspx

Norris, E. et al. (2014). Doing them justice. Lessons from four cases of policy implementation. Sydney: University of Sydney.

Oromia Economist. (2015). Oromia-OFCS letter to the diplomatic community. Retrieved November 10, 2017, from https://oromianeconomist.com/

Parker, M. H., \& Rutter, R. (2011). Policymaking in the real world: Evidence and analysis. Texas: University of Texas Southwestern Medical Center.

Patton, C., \& Sawicki, D. (1993). Basic methods of policy analysis and planning. Health, 6(21), 25-30.

Pica-Ciamarra, U. (2009). Basics in policy analysis: How governments should design \& implement policies. New York: Columbia University.

Political Pipeline. (2013). Top-down and bottom-up approaches within implementation. Annals of the American Academy of Political and Social Science, 581, 22-34.

Roberta, K., \& Vita, J. (2012). Good governance as the instrument for the implementation of the development concept. U.S.A.: Illinois University.

Roh, K. A. (2015). Challenges to policy implementation: An examination of an integrated health care. London.

Shughart, W. F. (2008). Public choice. The Concise Encyclopedia of Economics.

Store Sansar. (2010). Introduction to Public policy analysis. United of Kingdom.

Thomas, O. J., \& Onkware, K. (2015). The challenges of public policy formulation and evaluation through the questions what, who, how, and when?. Kenya.

Trivedi, V. (2012). In-situ conservation of biodiversity. University of Greenwich.

UNCRD expert group meeting. (2013). Integrated regional development planning. Nagoya, Japan: Nagoya University. 
UNESCAP. (2006). 10 Regional consultative meeting on good urban governance. Economic and Social Commission for Asia and the Pacific.

USA Department of State. (2011). Policy making in America. U.S.A.: USA Department of State.

Valire, C. C., \& Sandra, W. (2015). Policy implementation in social welfare. The Journal of Sociology \& Social Welfare, $15,15-20$.

Vilnius. (2014). Strategic planning for regional development: An introductory textbook. Stockholm, Sweden: Karolinska Institutet.

Walelign, T. (2015). Integrated approaches to sustainable development planning and implementation: Strengthening policy coherence for SD planning and implementation in Ethiopia. Retrieved November 15, 2017, from http://www.policyproject.com/policycircle/content.cfm?a $0=4$

Wang, Q. (2015). Conflict management. U.S.A.: Villanova University.

Wenger, R. (1976). Citizen participation: Practice in search of a theory. New York.

Wikipedia. (n.d.). Participatory democracy. Retrieved November 17, 2017, from https://en.wikipedia.org/wiki/Participatory_democracy

Wiley, J., \& Sons, S. (2000). Policy analysis: A systematic approach to supporting policymaking in the public sector.

William, J. et al. (1995). Conservation of biodiversity and the new regional planning. Contemporary Accounting Research, 34(2), 697-725.

William, M. K. (2006). Web Centre for Social Research. Retrieved November 17 2017, from https://socialresearchmethods.net/

World Bank Group. (2015a). Global practice on social, urban, rural and resilience. Retrieved November 17, 2017 from http:// www.worldbank.org/urban

World Bank Group. (2015b). Addis Ababa, Ethiopia: Enhancing urban resilience. Retrieved November 172017 , from https://openknowledge.worldbank.org/handle/10986/23245

Yehezkel, D. (n.d.). Policy Analysis: A theoretic framework and some basic concepts.

\section{Copyrights}

Copyright for this article is retained by the author(s), with first publication rights granted to the journal.

This is an open-access article distributed under the terms and conditions of the Creative Commons Attribution license (http://creativecommons.org/licenses/by/4.0/). 